\title{
Response of Egg Number to Selection of Different Genotypes of 24- bp Insertion-Deletion Locus in the Promoter of Prolactin Gene of Papua Local Chickens
}

\author{
Muhammad Affan Mu'in* and Sintje Lumatauw \\ Faculty of Animal Science, Papua University, Manokwari 98314, West Papua, Indonesia \\ *Corresponding author email: muinunipa@gmail.com
}

\begin{abstract}
This study aims to estimate the response of the number of eggs produced up to 240 days of age $\left(\mathrm{EN}_{240}\right)$ to the selection of Papua local chickens (PLC) with different genotypes from the 24-bp Indel CPRLp locus. A total of 68 PLCs were taken randomly from several breeders in Manokwari as the basic population for selection (G0). Genotype identification of the 24-bp Indel cPRLp locus was performed G0. Based on the distribution of these genotypes, mating pairs were randomly formed G0-II, GO-DD and G0-ID to produce G1-II, G1-DD, and G1-Control (G0-ID offspring). Heritability of $\mathrm{EN}_{240}$ in G1-II and G1-DD populations were estimated in full-sib (single pairs mating). Individual selection based on breeding value $\mathrm{EN}_{240}$ was carried out on G1-II (P) and G1-DD (P) to form the selection generation (GS): GS-II (ㅇ) and GS-DD (P). Selection was also carried out on G1II $\left(O^{\lambda}\right)$ and G1-DD $\left(O^{\lambda}\right)$ based on body weight at 240 days $\left(B_{240}\right)$ to become selected GS-II (P) and GS-DD (q) mating partners. GS-Control was also formed through $25 \%$ random sampling from G1-Control ( $\delta$ and $\bigcirc$ ). GS mating resulted in the second generation (G2): G2-II, G2-DD, and G2-Control. Age at first laying (AFL), EN 240 , and mean egg weight (EWA) in hens of G1, GS, and G2 were recorded. Response to selection for $\mathrm{EN}_{240}$ was calculated by two methods predicted selection response ( $\mathrm{Rp}$ ) and actual selection response ( $\mathrm{Rr}$ ). Both methods of calculation yield positive and high values. In actual response (Rr), PLC in II genotypes group are more responsive to the selection treatment than DD genotype group. Selection increase $\mathrm{EN}_{240}$ impact accelerate of AFL and lower the EWA, because of their negative genetic correlation.
\end{abstract}

Keywords: Papua local chickens, a 24-bp Indel/cPRLp locus, egg number, response to selection

\begin{abstract}
Penelitian ini bertujuan untuk memperkirakan respon jumlah telur yang dihasilkan hingga umur 240 hari (EN240) terhadap seleksi ayam lokal Papua (PLC) dengan genotipe yang berbeda dari lokus CPRLp Indel 24bp. Sebanyak 68 PLC diambil secara acak dari beberapa breeder di Manokwari sebagai populasi dasar seleksi (GO). Identifikasi genotipe lokus CPRLp Indel 24-bp ditunjukkan sebagai GO. Berdasarkan sebaran genotipe tersebut, pasangan kawin secara acak membentuk G0-II, G0-DD dan G0-ID untuk menghasilkan G1-II, G1-DD, dan G1-Control (keturunan G0-ID). Heritability of $\mathrm{EN}_{240}$ in G1-II and G1-DD populations were estimated in fullsib (single pairs mating). Heritabilitas EN240 pada populasi G1-II dan G1-DD diperkirakan bersaudara penuh (kawin berpasangan tunggal). Seleksi individu berdasarkan nilai pemuliaan EN240 dilakukan pada G1-II (ㅇ) dan G1-DD (P) untuk membentuk generasi seleksi (GS): GS-II (ㅇ) dan GS-DD (ㅇ). Seleksi juga dilakukan pada G1-II $\left(\hat{O}^{\top}\right)$ dan G1-DD ( $\hat{O}^{\wedge}$ ) berdasarkan berat badan pada 240 hari (BW240) untuk menjadi pasangan kawin terpilih GS-

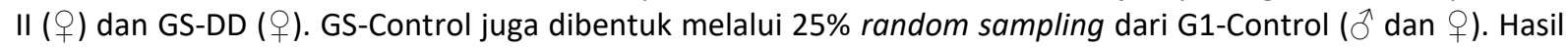
perkawinan GS menghasilkan generasi kedua (G2): G2-II, G2-DD, dan G2-Control. Usia saat pertama bertelur (AFL), EN240, dan rata-rata berat telur (EWA) pada ayam G1, GS, dan G2 dicatat. Respon terhadap seleksi untuk EN240 dihitung dengan dua metode respon seleksi prediksi (Rp) dan respon seleksi aktual (Rr). Kedua metode perhitungan tersebut menghasilkan nilai positif dan tinggi. Pada respon aktual (Rr), PLC pada kelompok genotipe II lebih responsif terhadap perlakuan seleksi dibandingkan dengan kelompok genotipe DD. Seleksi meningkatkan EN240 berdampak mempercepat AFL dan menurunkan EWA, karena korelasi genetik yang negatif.
\end{abstract}

Kata kunci: ayam lokal papua, lokus 24-bp Indel/cPRLp, jumlah telur, respon seleksi

\section{Introduction}

Papua local chickens (PLC) are phenotypically no different from native chickens found in various regions in Indonesia. However, the genetic constitution of the PLC population is thought to contain genes derived from superior laying hens from the Australorp and Barred Plymouth Rock breeds that were ever cultivated by a research institute in Manokwari during the 
Dutch colonial period (Kilmaskossu, 2010: Personal Communication).

In general, PLC is the same as other native chickens, which has broodiness behaviour. Broodiness or incubation behaviour occurs when the secretion of the hormone prolactin in the body increases (Alipanah et al., 2011), which causes ovary regression (Sharp et al., 1984) and ends egg-laying activity (Sockman et al., 2000), which in turn decreases egg production (Reddy et al., 2002). According to the observations of Tri-Yuwanta et al. (2002), breeders usually bathe hens that show incubation behaviour and then dry them in the sun for 3-5 consecutive days, and 10-15 days later, the hen will lay eggs again. Such practice allows the hens to lay more eggs in about 9-10 egg production cycles per year (Tri-Yuwanta et al., 2002).

With the development of molecular biology techniques today, it is very possible that the brooding behavior of PLC can be permanently eliminated. Genetically, chicken prolactin (cPRL) is encoded by a gene (Miao et al., 1999; Au and Leung, 2000). The 24-bp InDel (InsertionDeletion) mutation that occurs at the -358 site in the prolactin gene promoter region causes the CPRL gene to be unable to express its products and results in absence of the brooding behavior, causing the number of eggs produced to increase (Cui et al. , 2006; Begli et al., 2010; Rashidi et al., 2012).

With the PCR technique using a pair of primers: forward, 5'-ttt-aat-att-ggt-ggg-tga-agagac-a-3 ', and reverse, 5'-atg-cca-ctg-atc-ctc-gaaaac-tc-3 '(Cui et al., 2006) in PCR conditions: initial denaturation of $94^{\circ} \mathrm{C} 5$ minutes, continued with 35 cycles of amplification (denaturation of $94^{\circ} \mathrm{C} 30$ seconds, annealing $54^{\circ} \mathrm{C} 30$ seconds, extension $72^{\circ} \mathrm{C} 30$ seconds), and final extension $72^{\circ} \mathrm{C} 5$ minutes, three genotypes of the 24-bp InDel/cPRLp locus were found on PLC: II (Insertion Insertion), ID (Insertion-Deletion), and DD (Deletion-Deletion) (Mu'in and Lumatauw, 2018). The II genotype chickens can reduce CPRL expression so that it does not have incubation behavior (Jiang et al. 2005), and the presence of the I-allele in chickens has a positive impact on the number of eggs produced (Cui et al., 2006; Begli et al., 2010; Rashidi et al. , 2012).

This finding raises the hope that the problem of incubation behavior in PLC can be eliminated permanently, and that superior PLC in laying eggs can be realized in the future through the selection of increased egg numbers on PLC based on the 24-bp InDel marker in the promoter region of prolactin gene. The selection method is the right method to be applied to local chickens because it can improve the desired traits while maintaining the purity of the local chickens. Application of "Marker Assisted Selection (MAS)" can accelerate genetic improvement, because this selection method is free from environmental effects, can be applied to livestock as early as possible, and is not limited to specific sex (Smith and Brascamp, 1990). This study aims to determine the differences in the response of the egg number to the selection treatment on PLC of II and DD genotypes from the 24-bp InDel locus in the pomoter region of prolactin gene.

\section{Materials and Methods}

This research was conducted at the Experimental Farm, Faculty of Animal Science, University of Papua, Manokwari, West Papua Province, Indonesia. The study lasted from Maret 2018 to November 2020. The flow chart of research activities is presented in Figure 1.

A total of 68 (34 pairs) Papua local chickens were taken randomly from several farms in the Manokwari region, West Papua Province, Indonesia, and were used in this study as the baseline population for selection (G0). Identification of the 24-bp Indel cPRLp locus genotype by $P C R$ technique on $G 0$ has been carried out in previous studies (Mu'in and Lumatauw, 2018). 


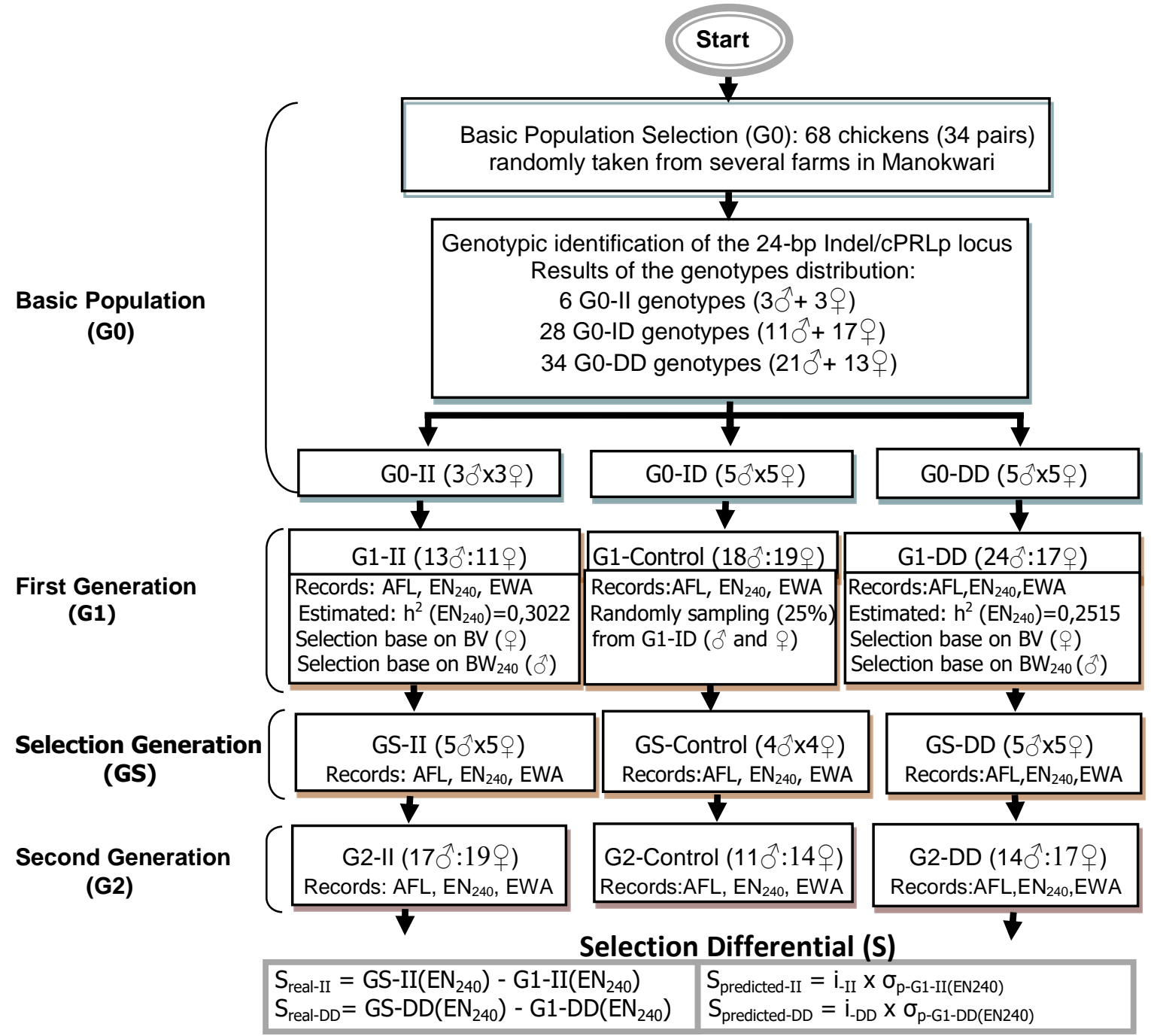

Response of Egg Number $\left(\mathrm{EN}_{240}\right)$ to Selection (R):

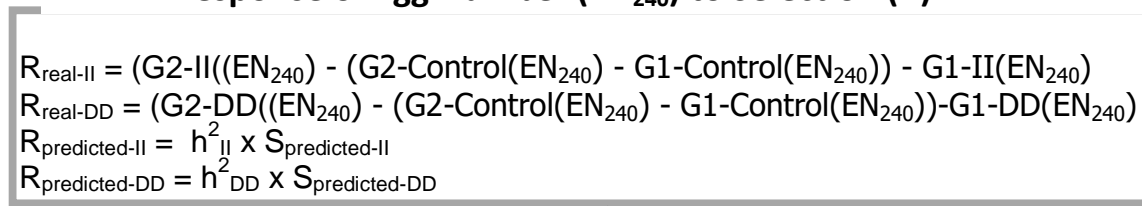

Information:

$\mathrm{AFL}=$ Age of first egg laying (day); $\mathrm{EN}_{240}=$ Egg number to 240 days of age (egg); $\mathrm{EWA}=$ Egg weight average to 240 days of age $(\mathrm{g} / \mathrm{egg}) ; \mathrm{BV}=$ Breeding value; $\mathrm{BW}_{240}=$ Body weight at 240 days; $\mathrm{S}_{\text {-realized-II }}=$ realized differential selection of II-genotype group; $S_{\text {-realized-DD }}=$ realized differential selection of DD-genotype group; $S_{\text {-predicted-II }}=$ predicted differential selection of IIgenotype group; $S_{\text {-predicted-DD }}=$ predicted differential selection of DD-genotype group; $i_{-11}=$ selection intensity of II-genotype group; $i_{-D D}=$ selection intensity of DD-genotype group; $\sigma_{p-G 1-I(E N 240)}=$ deviation standard of $E_{240}$ in G1-II group; $\sigma_{p-G 1-D D(E N 240)}$ = deviation standard of $\mathrm{EN}_{240}$ in $\mathrm{G1}-\mathrm{DD}$ group; $\mathrm{R}_{\text {realized-II }}=$ realized response of egg number $\left(\mathrm{EN}_{240}\right)$ to selection in II-genotype group; $R_{\text {realized-DD }}=$ realized response of egg number $\left(E N_{240}\right)$ to selection in DD-genotype group; $R_{\text {predicted-II }}=$ predicted response of egg number $\left(\mathrm{EN}_{240}\right)$ to selection in II-genotype group; $\mathrm{R}_{\text {predicted-DD }}=$ predicted response of egg number $\left(\mathrm{EN}_{240}\right)$ to selection in DD-genotype group; $h^{2}{ }_{\|}=$heritability of $\mathrm{EN}_{240}$ trait of II-genotype group; $h^{2}{ }_{D D}=$ heritability of $E N_{240}$ trait of DDgenotype group.

Figure 1. Flowchart of Research Activities 
The results of genotypic identification were found 6 chickens ( $3{ }^{\lambda}: 3+$ ) G0-II, 34 chickens

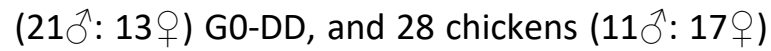
G0-ID. Based on the distribution of the GO genotypes found, done formation randomly 3 pairs of GO-II mated group, 5 pairs of GO-DD mated group, and 5 pairs of G0-ID mated group.

The mating of $G 0$ produced the first generation (G1): the G1-II (13 0 : 11우), G1-DD

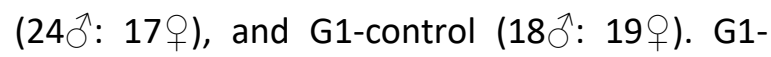
control is the offspring of G0-ID. The G1 chicks were kept in a brooder for 30 days, then kept in a rearing cage for 90 days, wing tagged and sexed. Furthermore, females reared in individual cages, recorded the age at first laying eggs (days), the number of eggs produced (eggs) to the age of 240 days $\left(E_{240}\right)$, and the average egg weight $(\mathrm{g})$ of $\mathrm{EN}_{240}$. Meanwhile, males are kept in limited yards and weighed at age 240 days $\left(\mathrm{BW}_{240}\right)$. During the maintenance of chickens are given commercial chicken feed with a protein content of $20 \%$.

In population $\mathrm{G} 1($ ( ) ), the heritability of EN240 was estimated based on full-sib data analysis. The variance component to estimate the $h 2$ value was obtained from analysis of variance (unidirectional pattern) and the separation of variance components for single pair mating (Becker, 1975). The estimation results of h2 \pm SE (EN240) for G1-II, G1-DD, and G1-control were $0.3022 \pm 0.2002 ; 0.2515 \pm$ 0.1180 ; and $0.3429 \pm 0.1233$, respectively. Furthermore, individual selection was carried out based on breeding values (EN240) above the average, both in G1-II ( + ) and G1-DD ( + ), to form the selection generation: GS-II ( $P$ ) and GSDD (P). The breeding value (BV) of EN240 in individual $\mathrm{G1}($ ( $)$ was calculated using the formula (Hardjosubroto, 1994):

$$
B V=h j 2(\text { Pij }- \text { Prj) }
$$

Where:

Pij: EN240 the $\mathrm{i}$-th individual in the $\mathrm{j}$-th genotype group;
Prj: mean EN240 r-th in the j-th genotype group;

hj2: heritability of EN240 in the j-th genotype group.

Meanwhile, the selection of $G 1(\hat{\jmath})$ to become a mated partner $\mathrm{G} 1$ (ㅇ) was selected in a certain genotype group based on body weight at 240 days (BW240) above the average of the genotype group. In addition, GS-control was also formed by taking $25 \%$ of chickens randomly on G1-control ( $\hat{\sigma}$ and + ).

Based on the individual selection method above, GS-II (5 pairs) and GS-DD (5 pairs), as well as GS-control (4 pairs) were formed. The selection generation (GS) is formed to produce the second generation (G2). The GS that is formed is placed in a mated cage. The resulting eggs were collected for $2 \times 10$ days, then hatched. The eggs that hatch are G2, which

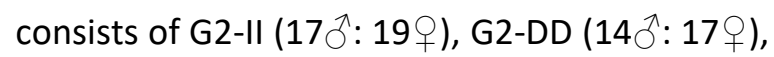
and G2-Control (11 $\left.\delta^{\lambda}: 14 \%\right)$. The G2 chickens were reared in a brooder for 30 days, then kept in a rearing cage for 90 days, given an identity (wing tag) and were sexed. Furthermore, for females reared in individual cages, the age at first laying eggs (days), EN240 (eggs), and the average egg weight (g) was recorded from EN240. Commercial chicken feed with a protein content of $20 \%$ is provided during maintenance.

In this study, actual and predicted of response of egg number (EN240) to selection were calculated (Hardjosubroto, 1994).

$$
\begin{aligned}
& \text { Actual Selection Response (see Figure 1) } \\
& S_{\text {-actual-II }}=\mathrm{EN}_{240}(\mathrm{GS}-\mathrm{II})-\mathrm{EN}_{240}(\mathrm{G} 1-\mathrm{II}) \\
& \begin{aligned}
S_{\text {-actual-DD }}= & \mathrm{EN}_{240}(\mathrm{GS}-\mathrm{DD})-\mathrm{EN}_{240}(\mathrm{G} 1-\mathrm{DD}) \\
R_{\text {-actual-II }}= & \left(\mathrm{EN}_{240}(\mathrm{G} 2-\mathrm{II})-\left(\mathrm{EN}_{240}(\mathrm{G} 2 \text {-Control)- }\right.\right. \\
& \left.\left.\mathrm{EN}_{240}(\mathrm{G} 1-\mathrm{Con} \text { trol })\right)\right)-\mathrm{EN}_{240}(\mathrm{G} 1-\mathrm{II}) \\
R_{\text {-actual-DD }}= & \left(\mathrm{EN}_{240}(\mathrm{G} 2-\mathrm{DD})-\left(\mathrm{EN}_{240}(\mathrm{G} 2 \text {-Control)- }\right.\right. \\
& \left.\left.\mathrm{EN}_{240}(\mathrm{G} 1-\text { Control })\right)\right)-\mathrm{EN}_{240}(\mathrm{G} 1-\mathrm{DD})
\end{aligned}
\end{aligned}
$$


Where:

$\mathrm{S}_{\text {-actual-II }}=$ actual differential selection of IIgenotype group;

$\mathrm{S}_{\text {-actual-DD }}=$ actual differential selection of DDgenotype group;

$\mathrm{EN}_{240}$ (GS-II)= egg number to 240 days of age (egg) of GS-II group;

$\mathrm{EN}_{240}(\mathrm{G} 1-\mathrm{II})=$ egg number to 240 days of age (egg) of G1-II group;

$\mathrm{EN}_{240}$ (GS-DD)= egg number to 240 days of age (egg) of GS-DD group;

$\mathrm{EN}_{240}(\mathrm{G} 1-\mathrm{DD})=$ egg number to 240 days of age (egg) of G1-DD group;

$\mathrm{R}_{\text {-actual-II }}=$ actual selection response of egg number (EN240) of II-genotype group;

$\mathrm{R}_{\text {-actual-DD }}=$ actual selection response of egg number $\left(E_{240}\right)$ of DD-genotype group;

$\mathrm{EN}_{240}(\mathrm{G} 2-\mathrm{II})=$ egg number to 240 days of age (egg) of G2-II group;

$\mathrm{EN}_{240}(\mathrm{G} 2-\mathrm{DD})=$ egg number to 240 days of age (egg) of G2-DD group;

$\mathrm{EN}_{240}$ (G2-Control)= egg number to 240 days of age (egg) of G2-Control group;

$\mathrm{EN}_{240}$ (G1-Control)= egg number to 240 days of age (egg) in G1-Control group;

$\mathrm{EN}_{240}$ (G1-II)= egg number to 240 days of age (egg) of G1-II group;

$\mathrm{EN}_{240}(\mathrm{G} 1-\mathrm{DD})=$ egg number to 240 days of age (egg) of G1-DD group;

\section{Predicted Selection Response}

$\mathrm{S}_{\text {-predicted-II }}=\mathrm{i}_{-\| l} \times \sigma_{\mathrm{p}(\mathrm{G1}-\|)}$

$\mathrm{S}_{\text {-predicted-DD }}=\mathrm{i}_{-\mathrm{DD}} \times \sigma_{\mathrm{p}(\mathrm{G1}-\mathrm{DD})}$

$\mathrm{R}_{\text {-predicted-II }}=\mathrm{h}_{\|}^{2} \times \mathrm{S}_{\text {-predicted-II}}$

$\mathrm{R}_{\text {-predicted-DD }}=\mathrm{h}^{2}{ }_{\mathrm{DD}} \times \mathrm{S}_{\text {-predicted-DD }}$

Where:

$\mathrm{S}_{\text {predicted-II }}=$ predicted of differential selection of the II-genotype group;

$\mathrm{S}_{\text {predicted-DD }}=$ predicted of differential selection of the DD-genotype group;

$\mathrm{i}_{-\|}=$selection intensity of the II-genotype group;
$\mathrm{i}_{-D D}=$ selection intensity of the DD-genotype group;

$\sigma_{p(G 1-I I)}=$ deviation standard of $E_{240}$ in G1-II group;

$\sigma_{p(G 1-D D)}=$ deviation standard of $\mathrm{EN}_{240}$ in G1-DD group;

$R_{\text {predicted-II }}=$ predicted of response of egg number $\left(E N_{240}\right)$ to selection in II-genotype group;

$\mathrm{R}_{\text {predicted-DD }}=$ predicted of response of egg number $\left(E_{240}\right)$ to selection in DD-genotype group;

$\mathrm{h}^{2}{ }_{\text {II }}=$ heritability of $\mathrm{EN}_{240}$ trait of the II-genotype group;

$\mathrm{h}_{\mathrm{DD}}^{2}=$ heritability of $\mathrm{EN}_{240}$ trait of the DDgenotype group.

\section{Results and Discussion}

The results of recording the age at first laying eggs (days), egg number to 240 days of age (eggs) and egg weight average (g/egg) produced during the period from first laying to the age of 240 days in the first generation (G1), the selection generation (GS), and the second generation (G2), are shown in Table 1.

The results of statistical analysis showed that the differences in the genotype group of the research chickens in $\mathrm{G} 1$ and $\mathrm{G} 2$ had a significant effect $(P<0.05)$ on $A F L, E N_{240}$, and EWA. In $G 2$, it was found that $E N_{240}$ on $G 2-I 1$ was higher ( $P$ $<0.05)$ than $\mathrm{EN}_{240}$ on $\mathrm{G} 2-\mathrm{DD}$ and $\mathrm{EN}_{240}$ on G2control. However, $\mathrm{EN}_{240}$ on G2-DD was not different $(P>0.05)$ with $\mathrm{G} 2$-control. This shows that the selection for increasing the number of eggs in chicken II-genotype have a higher response than the same selection applied to chicken DD-genotype. This is in accordance with the opinion of Sartika (2005) who states that if the genotype selection of the prolactin promoter as a genetic marker (MAS) is carried out in native chickens in the basic population, the response to egg production selection will be faster and more accurate. 
Table 1. Average age of first egg laying (AFL), egg number to 240 days of age $\left(\mathrm{EN}_{240}\right)$ and egg weight average (EWA) to 240 days of age in Papua local chickens

\begin{tabular}{|c|c|c|c|c|c|c|c|}
\hline $\begin{array}{l}\text { Genotype Group/ } \\
\text { Generation }\end{array}$ & $\mathrm{n}$ & $\begin{array}{l}\text { AFL } \\
\text { (day) }\end{array}$ & $\begin{array}{l}\mathrm{CV} \\
(\%)\end{array}$ & $\begin{array}{l}\mathrm{EN}_{240} \\
\text { (egg) }\end{array}$ & $\begin{array}{l}\mathrm{CV} \\
(\%)\end{array}$ & $\begin{array}{l}\text { EWA } \\
\text { (g/egg) }\end{array}$ & $\begin{array}{l}\mathrm{CV} \\
(\%)\end{array}$ \\
\hline \multicolumn{8}{|c|}{ 1. $1^{\text {st }}$ generation (G1) } \\
\hline G1-II & 11 & $145,2 \pm 3,6^{\mathrm{a}}$ & 2,5 & $41,1 \pm 3,4^{a}$ & 8,3 & $35,8 \pm 3,6^{a}$ & 10,1 \\
\hline G1-DD & 17 & $149,9 \pm 5,6^{b}$ & 3,7 & $38,2 \pm 4,7^{\mathrm{ab}}$ & 12,3 & $40,4 \pm 3,6^{b}$ & 8,9 \\
\hline G1-control & 19 & $151,0 \pm 5,1^{\mathrm{b}}$ & 3,4 & $36,6 \pm 4,8^{b}$ & 13,1 & $41,0 \pm 2,9^{b}$ & 7,1 \\
\hline \multicolumn{8}{|c|}{ 2. Selection generation (GS) } \\
\hline GS-II & 5 & $143,2 \pm 4,3^{\mathrm{a}}$ & 3,0 & $44,0 \pm 1,0^{a}$ & 2,3 & $34,2 \pm 1,7^{\mathrm{a}}$ & 5,0 \\
\hline GS-DD & 5 & $144,8 \pm 3,6^{\mathrm{a}}$ & 2,5 & $43,6 \pm 2,7^{\mathrm{a}}$ & 6,2 & $36,2 \pm 1,6^{\mathrm{ab}}$ & 4,4 \\
\hline GS-control & 4 & $151,5 \pm 6,9^{a}$ & 4,5 & $36,0 \pm 5,7^{b}$ & 15,8 & $40,5 \pm 4,1^{b}$ & 10,1 \\
\hline \multicolumn{8}{|c|}{ 3. $2^{\text {nd }}$ generation (G2) } \\
\hline G2-II & 19 & $145,3 \pm 3,2^{\mathrm{a}}$ & 2,2 & $43,4 \pm 2,6^{a}$ & 6,0 & $35,6 \pm 2,3^{a}$ & 6,6 \\
\hline G2-DD & 17 & $147,5 \pm 3,2^{a b}$ & 6,7 & $40,0 \pm 2,8^{b}$ & 7,0 & $38,3 \pm 3,2^{\mathrm{ab}}$ & 8,3 \\
\hline G2-control & 14 & $150,9 \pm 5,5^{b}$ & 3,6 & $37,4 \pm 4,0^{b}$ & 10,7 & $40,7 \pm 3,9^{b}$ & 9,6 \\
\hline
\end{tabular}

Different superscripts in the same column and serial number indicated a significant difference $(P<0.05)$. G1-II: offspring from the results mating basic population II $\hat{o} \mathrm{x} \|$ 우; G1-DD: offspring from the results mating basic population DD $\hat{o} \mathrm{x}$ DD 우; G1-control: offspring from the results mating basic population ID $\hat{0}$ x ID 우; GS-II: Selected generation from G1-II; GSDD: Selected generation from G1-DD; GS-control: Papua local chickens group were take $25 \%$ random sample of from G1Control; G2-II: GS-II offspring; G2-DD: GS-DD offspring; G2-control: GS-Control offspring.

Research by Bagheri et al. (2013) found a significant relationship between the genotype at the 24-bp InDel/cPRLp locus and egg production of local chickens in Iran and supports the results of this study. According to his report, the number of eggs produced (\%) of local chickens in Iran with II, ID and DD genotypes were 52.03 $\pm 1.0^{\mathrm{a}}, 48.78 \pm 1.0^{\mathrm{a}}$, and $34.38 \pm 1.7^{\mathrm{b}}$, respectively. The results of the study by Bagheri et al. (2013) put II-genotype chickens in the position of the highest egg producer and chicken with DD-genotype in the lowest position. When compared with the results of this study, it can be seen that the selection of increasing the number of eggs carried out in II and DD-genotypes chickens still positions the genotyped II chickens in a position that produces a higher number of eggs compared to the DD-genotype chickens.

In Table 1, it can be seen that EN240 in G2 still has a relatively high coefficient of variation, both in G2-II and G2-DD. However, the coefficient of variation in $\mathrm{G} 2$ is lower than G1. The decrease in the coefficient of variation is more contrasted when the two chickens groups (G2-II and G2-DD) are compared to a control chickens group of the same generation (G2control). This shows that selection is able to reduce EN240 variations in the two selected genotype groups (G2-II and G2-DD).

The high and low of egg number $\left(\mathrm{EN}_{240}\right)$ in the research chickens in all genotype groups in all generations were seen to have an impact on the age at first laying eggs (AFL) and egg weight average (EWA) (Table 1). Both phenotypic and genetic correlations between the three traits are thought to have occurred in this study. This is a common phenomenon in poultry and has been widely reported by researchers. Hu et al. (2004) stated a negative genetic correlation between the age at first laying of eggs and the number of eggs produced on selected Muscovy ducks in Taiwan. Francesch et al. (1997) also reported a negative genetic correlation between egg number and egg weight in three Catalan breeds, namely Penedesenca Negra, Prat Leonada Empordanesa Roja. Realizing this phenomenon, it is important to consider the selection of an increase in egg number at an optimum point where the weight of the eggs produced is still acceptable for consumers. 
Table 2. Selection Response of the egg number to 240 days of age $\left(E_{240}\right)$ in Papua lokal chickens

\begin{tabular}{cccccccccc}
\hline $\begin{array}{c}\text { Genotype } \\
\text { group }\end{array}$ & $\begin{array}{c}\mathrm{h}^{2} \\
\left(\mathrm{EN}_{240}\right)\end{array}$ & $\mathrm{G} 1\left(\mathrm{EN}_{240}\right)$ & $\mathrm{GS}\left(\mathrm{EN}_{240}\right)$ & $\begin{array}{c}\mathrm{G} 2 \\
\left(\mathrm{EN}_{240}\right)\end{array}$ & $\mathrm{i}$ & $\mathrm{S}_{\mathrm{r}}$ & $\mathrm{S}_{\mathrm{p}}$ & $\mathrm{R}_{\mathrm{r}}$ & $\mathrm{R}_{\mathrm{p}}$ \\
\hline $\mathrm{II}$ & 0.3022 & $41.1 \pm 3.4$ & $44.0 \pm 1.0$ & $43.4 \pm 2.6$ & 0.880 & 2.900 & 2.992 & 1.500 & 0.9042 \\
$\mathrm{DD}$ & 0.2515 & $38.2 \pm 4.7$ & $43.6 \pm 2.7$ & $40.0 \pm 2.8$ & 1.180 & 5.400 & 5.546 & 1.000 & 1.3948 \\
Control & - & $36.6 \pm 4.8$ & $36.0 \pm 5.7$ & $37.4 \pm 4.0$ & - & - & - & - & - \\
\hline
\end{tabular}

$\mathrm{h}^{2}\left(\mathrm{EN}_{240}\right)=$ heritability of $\mathrm{EN}_{240}$ in the first generations; $\mathrm{G1}\left(\mathrm{EN}_{240}\right)=\mathrm{EN}_{240}$ average in the first generation; $\mathrm{GS}\left(\mathrm{EN}_{240}\right)=\mathrm{EN}_{240}$ average in the selection generation; $\mathrm{G}_{2}\left(\mathrm{EN}_{240}\right)=\mathrm{EN}_{240}$ average in the second generation; $\mathrm{S}_{\mathrm{r}}=$ actual differential selection $\left(\mathrm{S}_{\mathrm{r}}\right.$ II $\left.=G S-I I\left(E N_{240}\right)-G 1-I I\left(E_{240}\right) ; S_{r-D D}=G S-D D\left(E N_{240}\right)-G 1-D D\left(E N_{240}\right)\right) ; i=$ selection intensity $\left(i_{-11}=5 / 11=0.45=0.880 ; i_{-D D}=5 / 17\right.$ $=0.29=1.180) ; S_{p}=$ predicted differential selection $\left(S_{p-\| I}=i_{-\|} \times \sigma_{p-G 1-\|} ; S_{p-D D}=i_{-D D} \times \sigma_{p-G 1-D D}\right) ; R_{r}=$ actual selection response $\left(R_{r-}\right.$ $\|=\left(G 2-I I\left(E_{240}\right)-\left(G 2-C o n t r o l\left(E N_{240}\right)-G 1-C o n t r o l\left(E N_{240}\right)\right)-G 1-I I\left(E N_{240}\right) ; R_{r-D D}=\left(G 2-D D\left(E N_{240}\right)-\left(G 2-C o n t r o l\left(E N_{240}\right)-G 1-\right.\right.\right.$ Control $\left.\left.\left(E_{240}\right)\right)-G 1-D D\left(E N_{240}\right)\right) ; R_{p}=$ predict selection response $\left(R_{p-I I}=h^{2}{ }_{\|} \times S_{p-\| l} ; R_{p-D D}=h_{D D}^{2} \times S_{p-D D}\right)$.

In this study, the AFL of G2-II and G2-DD tended to lead to the appearance of Black Kedu chickens, which was 138 days, while in the control group (G2-control) such as native chickens in general, it was 151 days (Creswell and Gunawan, 1982). In addition, the three genotype groups in $\mathrm{G} 2$ are in the first age range to lay eggs as shown by KUB chickens, namely the age of 20-22 weeks or around the age of 140-154 days (Iskandar and Sartika, 2014; Hidayat, et al., 2011 ). The EWA of G2-II and G2DD tends to be close to the average egg weight during production of 35\% (chicken age 29 weeks) in KUB chickens, which weighs 38.56 g/egg (Romjali, et al., 2019).

The results of the selection of increasing the egg number (G2) produced EN240 of $43.4 \pm 2.6$ eggs ( $\pm 45.8 \%$ Hen Day) in G2-II and $40.0 \pm 2.8$ eggs ( $\pm 43.2 \%$ Hen Day) on G2-DD, while in the control group (G2-control) the egg number was $37.4 \pm 4.0$ eggs ( $\pm 41.9 \%$ Hen Day). The egg number produced (EN240) by G2-II is close to the egg number produced by KUB chickens (45 $50 \%$ Hen Day) as reported by Iskandar and Sartika (2014) and Hidayat, et al. (2011), while the egg number (EN240) in G2-DD and the control group (G2-control) was still far below the egg number produced by KUB chickens.

Table 2 shows that the actual selection response $\left(R_{r}\right)$ and predicted $\left(R_{p}\right)$ of EN240, both in genotype II and DD groups were still positive. Hardjosubroto (1994) states that a positive selection response indicates that the genetic variation of the selected trait is still high. This means that the selection in this population can be continued on the next generation to produce the maximum genetic improvement progress or result in the selection minimal response. In other words, the selection increase EN240 in local chicken Papua is still effective when performed in the 2 nd generation to produce the next generation.

The selection response is an increase in the average phenotype value of the next generation as a result of the selection of the previous population. Hardjosubroto (1994) states that the selection response obtained based on predictions is not always the same as the selection response based on reality. According to him, this situation is due to the influence of environmental factors that cannot be controlled and cannot be taken into account in the analysis. In Table 2, this situation shows, where the estimated selection differential (Sp) obtained is almost the same as the reality selection differential $\left(\mathrm{S}_{\mathrm{r}}\right)$, but after the influence of the environment, the resulting selection response $(\mathrm{Rr})$ has deviated from the predicted results $\left(R_{p}\right)$. By comparing the actual selection response $(\mathrm{Rr})$ in the two genotype groups (II and DD) (Table 2), it can be concluded that EN240 in the II genotype group still has a greater chance of being increased again than EN240 in the DD genotype group. 


\section{Conclusions}

The selection treatment increased egg number to 240 days of age (EN240) in Papua local chickens. This was indicated by the positive and high selection response. The II genotype group was more responsive to this selection treatment than the DD genotype group, it was proven that actual selection response of the IIgenotype group was higher. The increase in EN240 as a result of this selection treatment resulted in a decrease in egg weight average (EWA) and an accelerated age at first laying $(A F L)$ due to negative genetic correlation.

\section{Acknowledgement}

Thank you to the Directorate of Research and Community Service, Directorate General of Research and Development Strengthening, Ministry of Research, Technology and Higher Education, which has funded this research based on Decree Number SP DIPA042.06.1.401516/2020 and Agreement/Contract Number 198/SP2H/ LT / DRPM / 2020.

\section{References}

Alipanah M, K Shojaian and HK Bandani. 2011. The Polymorphism of prolactin gene in native chicken Zabol region. Journal of Animal and Veterinary Advance. 10(5): 619-621.

$\mathrm{Au}$ WL and FC Leung. 2000. Genomic sequence of chicken prolactin gene. Departement of Zoology, The University of Hongkong, Pokfulam Road, Hongkong, SAR, China. www.ncbi.nlm.nih.gov/entrez/viewer.fcgi?dbNucleotide \&dopt-GenBank (20 Februari 2014).

Bagheri SAS, A Niazi, MJ Zamiri and MD Taromsari. 2013. Polymorphisms of prolactin gene in a native chicken population and its association with egg production. Iranian Journal of Veterinary Research. 14 (2): 113-119.

Begli HE, S Zerehdaran, S Hassani, MA Abbasi and AK Ahmadi. 2010. Polymorphism in prolactin and PEPCK-C genes and its association with economic traits in native fowl of Yazd province. Iranian Journal of Biotechnology. 8:172-177.

Creswell DC dan B Gunawan. 1982. Ayam-ayam lokal di Indonesia: Sifat-sifat produksi pada lingkungan yang baik. Laporan No. 2. Balai Penelitian Ternak, Bogor, Indonesia. Pp 9-14.
Cui JX, HL Du, Y Liang, XM Deng, N Li and XQ Zhang. 2006. Association of polymorphism in the promoter region of chicken prolactin with egg production. Poultry Science. 85:26-31.

Francesch A, J Estany, L Alfonso and M Iglesias. 1997. Genetic parameters for egg number, egg weight, and egg shell color in three Catalan poultry breeds. Poultry Science. 76:1627-1631.

Hardjosubroto W. 1994. Aplikasi Pemuliabiakan Ternak di Lapangan. GramediaWidiasarana Indonesia, Jakarta.

Hidayat C, S Iskandar dan T. Sartika. 2011. Respon kinerja perteluran ayam Kampung Unggul Balitnak (KUB) terhadap perlakuan protein ransum pada masa pertumbuhan. Jurnal IImu Ternak dan Veteriner (JITV). 16:83-89.

Hu YH, JP Poivey, R Rouvier, SC Liu and C Tai. 2004. Heritabilities and genetic correlations of laying performance in Muscovy ducks selected in Taiwan. Journal British Poultry Science. 45(2):180-185.

Iskandar S and T Sartika. 2014. KUB chicken: The first Indonesian Kampung chicken selected for egg production. Proceedings of the 16th AAAP Animal Science Congress Vol II. , Yogyakarta (Indonesia): Gadjah Mada University:157-160.

Jiang RS, GY Xu, XQ Zhang and N Yang. 2005. Association of polymorphism for prolactin and prolactin receptor genes with broody traits in chickens. Poultry Science. 84:839-845.

Miao Y, DW Burt, IR Paton, PJ Sharp and IC Dunn. 1999. Mapping of the prolactin gene to chicken chromosome 2. Anim Genet. 30:473.

Mu'in MA and S Lumatauw. 2018. Potency of Papua local chickens as egg producers: a molecular review. 1st International Conference of Animal Science and Technology (ICAST) 2018. IOP Conf. Series: Earth and Environmental Science 247 (2019) 012032.

Rashidi H, G Rahimi-Mianji, A Farhadi and M Gholizadeh. 2012. Association of prolactin and prolactin receptor gene polymorphism with economic traits in breeder hens of indigenous chickens of Mazandaran province. Iranian Journal of Biotechnology. 10: 129-135.

Reddy IJ, CG David, PV Sarma and K Singh. 2002. The possible role of prolactin in laying performance and steroid hormone secretion in domestic hen (Gallus domesticus). Gen. Comp. Endocrinol. 127:249-255.

Romjali E, Subiharta, H Hasinah, FA Pamungkas dan R Matondang. 2019. Kinerja produksi dan reproduksi ayam KUB di peternak pembibit. Prosiding Seminar Nasional Teknologi Peternakan dan Veteriner 2019: 717-721.

Sartika T. 2005. Peningkatan Mutu Bibit Ayam Kampung Melalui Seleksi dan Pengkajian 
Penggunaan Penanda Genetik Promotor Prolaktin dalam MAS (Marker Assisted Selection) untuk Mempercepat Proses Seleksi. Disertasi Sekolah Pasca Sarjana Institut Pertanian Bogor, Bogor.

Sharp PJ, MC Mac Namee, RT Talbot, RJ Sterling and TR Hall. 1984. Aspects of the neuroendocrine control of ovulation and broodiness in the domestic hen. J. Exp. Zool. 232:475-483.

Smith RG and EW Brascamp. 1990. Genetic impact by advanced breeding technologies and gene transfer. In: Biotechnology for Control of Growth and Product Quality in Meat Production:
Implications and Acceptability. Proceedings of an International Symposium, Washington, D.C. (5-7 Dec. 1990).

Sockman KW, H Schwabl and PJ Sharp. 2000. The role of prolactin in the regulation of clutch size and onset of incubation behaviour in the American kestrel. Horm. Behav. 38:168-176.

Tri-Yuwanta, Nasroedin, Wihandoyo, Zuprizal and A Wibowo. 2002. The Role of Native Chicken in Indonesia Rural. Proceeding the 3rd ISTAP, Faculty of Animal Science, Gadjah Mada University, Yogyakarta. 